The rise and fall of life-wide learning for adults in England Alan Tuckett

University of Wolverhampton

\title{
Abstract
}

This article analyses policy and practice in social and cultural education for adults in England in the post Second World War era, beginning with the flowering of municipal adult education and the expansion of university extra-mural provision tracks the emerging policy focus on extending participation to under-represented groups, and on securing a rich breadth of curriculum (life-wide learning), which flowered in the 1990s. It maps, and deprecates the subsequent narrowing of public investment to an increasingly utilitarian focus on qualifications for labour market participation with the rise of Treasury (finance ministry) influence on adult learning policy from 2003. Evidence of the wider benefits that derive from participation in learning is used to re-assert the case for publicly accessible lifelong, life-wide education for adults.

Keywords: adult education; lifewide learning; politics; participation; England. 
Adult learning matters. It can transform lives, fire new enthusiasms and satisfy old curiosities. It can be a route to gain or maintain employment, and the means to sustain livelihood. It can offer second chances to people who missed out in their earlier education, and first chances to people who never had the chance to go to school. It offers opportunities for people to rub shoulders with others from all backgrounds - and to strengthen social capital (Baron et al, 2001). There is powerful evidence that adult learning has positive health effects, prolongs active life and shortens the period of morbidity (Feinstein et al, 2009). Participation in adult education is recognised as an effective preventative health measure for people at risk of mental illness, and a safe place to rebuild relationships when recovering (HMSO, 2008). Adults who learn have a positive impact on their families, too: in what the American academic Tom Sticht called a double duty dollar. Teach an adult, but especially a mother, and children will learn better, too (Sticht, 2001).

But as well as offering the potential for transformation, adult learning provision can, without a combination of public investment and effective targeting, reinforce inequality, and the marginalisation of 
marginalised groups. There is a wealth of evidence of the social and economic value of adult learning, and evidence aplenty of how to overcome the exclusion of marginalised groups (BIS 2012a). Yet despite this, current policy in England presages the eradication of large swathes of publicly funded adult education, accompanied by a dramatic weakening of public libraries. More than a third of further education colleges are already in financial crisis - having lost more than a quarter of their income since 2011. Two million adult learners in further education have been lost since 2004, (from 4,600,000 to $2,650,000$ adults) and provision is reducing dramatically (House of Commons, 2008:ev232; SFA/BIS 2016)

The situation for adults in higher education is no better: tripling of undergraduate student fees has led to a thirty percent drop in Open University student numbers, along with a marked decline in other parttime higher education participation by mature students at both undergraduate and postgraduate course level at a time when higher education as a whole is growing significantly. Adults seeking to change direction in mid-career, or to sustain their employment through acquiring complementary skills, are denied public funding if their 
course is at a similar or lower level to their existing highest qualification ${ }^{1}$.

At the same time there has been a reduction in workplace training with fewer employers offering training now than before the onset of the recession (LSC, 2008, UKCES 2014). The public investment in adult learning that survives is focused overwhelmingly on a peculiarly narrow range of utilitarian qualification-bearing vocational courses.

In an economy reliant upon migrant labour, and with large numbers of settled residents without the English language skills to participate fully in work and society, budgets for courses in English for Speakers of Other Languages have been reduced systematically. Demographic change means that the English economy has a labour market increasingly reliant on older workers prolonging their working lives, yet public support for workplace learning is limited to the young, and to securing 3 million apprentices by 2020 - when just 6 percent of young people take the apprenticeship route when leaving school.

In its Skills Outlook the Organisation for Economic Development and Co-operation, reporting on its study of the literacy, numeracy and information-processing skills of adults between the ages of 16-65

\footnotetext{
${ }^{1}$ The Equivalent and Lower Qualifications rule, which limits public funding and loans to higher education courses which are at a higher or equivalent level to that held currently by participants, was introduced as a cost saving measure in 2008.
} 
concluded that 'the results ... underline the need to move from a reliance on initial education towards fostering lifelong skills-oriented learning.' (OECD, 2013, 42). This advice is consistent with OECD analysis since the mid 1990s. It limits policy discussion of lifelong learning to labour market considerations, an approach that has been broadly endorsed, at least at the level of rhetoric, by governments across the political spectrum in England for the last decade. (Field 2006, Taylor 2005, Holford and Welikala 2013).

Peter Jarvis has always understood the value of learning at work: his first book was on Professional Education (Jarvis 1983); he has been an influential voice in nursing education (e.g. Jarvis 1992, 2005); while in work such as The Practioner-Researcher (Jarvis 1998) he examined how professionals learn, what professional practice is, and how education for practice can be enhanced. Yet at the same time he has argued powerfully that learning must not be about work-related skills alone. 'Learning is about becoming a person in society', and those who help people learn should do so 'to help the learners become fully human' (Jarvis 1992: 237, 240). I am therefore delighted to contribute to a 
volume celebrating and developing his work - like so many others I owe him a considerable debt. ${ }^{2}$

There is certainly a need for skills-oriented opportunities to learn throughout life, but policy and practice in England since the Second World War provides powerful evidence that a broader and more inclusive approach is more effective at engaging under-represented groups in learning as adults. The paper argues, too, that life-wide, as well as lifelong education is needed in order to fulfil people's wider aspirations, to foster their capacities, and to strengthen the possibilities adult learning offers as a catalyst in the achievement of other social policy goals: in short to become the best, together, that we can be. It argues that without that broader vision, the narrower labour market focused strategy will fail, as it is failing now in England (Fryer 2010).

\section{Political perspectives}

The case for life-wide learning, and its role in underpinning an inclusive, cultured and civilised society has been made at different times, graphically and persuasively, by politicians across the policy divide. In 1953, responding to a letter from the Trades Union Congress

\footnotetext{
${ }^{2}$ Among other things, Peter persuaded me in the mid 1980s of the potential power of participation research in identifying who is missing from provision as a stimulus to working out what could be done about it.
} 
complaining at cuts in university extra mural provision (which had tripled in scale since 1945), Winston Churchill argued:

There is, perhaps no branch of our vast educational system which should more attract within its particular sphere the aid and encouragement of the State than adult education. How many must there be in Britain, after the disturbance of two destructive wars, who thirst in later life to learn about the humanities, the history of their country, the philosophies of the human race, and the arts and letters which sustain and are borne forward by the ever-conquering English language?... I have no doubt myself that a man or woman earnestly seeking in grown-up life to be guided to wide and suggestive knowledge in its largest and most uplifted sphere will make the best of all the pupils in this age of clatter and buzz, of gape and gloat. The appetite of adults to be shown the foundations and processes of thought will never be denied by a British Administration cherishing the continuity of our Island life (Ministry of Education, 1954, 66-7).

Indeed, he argued that such studies were more important and deserving of support than technical education, important though that is. The proposed budget cut was, incidentally, reversed (Kelly 1970). 
More than forty years later, in his Preface to the government Green Paper, The Learning Age, the then Secretary of State, David Blunkett, put the case for life-wide learning well. Having highlighted Britain's proud tradition of men and women combining together to learn their way out of poverty, and to build through self-help mutual societies, trade unions, and civic institutions of learning like mechanics' institutes, Blunkett went on:

Learning enables people to play a full part in their community and strengthens the family, the neighbourhood and consequently the nation. It helps us fulfil our potential and opens doors to a love of music, art and literature. That is why we value learning for its own sake and are encouraging adults to enter and re-enter learning at every point of their lives as parents, at work and as citizens (Blunkett,1998, 5).

Other ministerial politicians have concurred, if with less eloquence. Among them were the Conservatives Tim Boswell, whose short spell as Minister for Further Education sparked a lifelong commitment to the cause of adult literacy, and John Hayes, who was taken by the dignity people derived from craft - making culture making things (Hayes 2010). The Liberal Democrat Secretary of State (2010-2015), Vince Cable spoke movingly of the impact participation in adult education classes 
had had on the life of his mother, in offering a place to rebuild dignity and a sense of purpose after debilitating illness, and of the route it offered to his father to become a college lecturer, sharing his engineering skills. And Cable defended community based learning budgets with determination, and at least early in the government's term in office, with success (Boseley, 2015). Labour also had its advocates for life-wide learning: Jennie Lee, who oversaw the establishment of the Open University, and John Denham, who recognised the value of self-help learning in enriching lives, particularly among older adults (Hollis 1998).

However, their voices, whilst memorable, stand out partly by being unusual and counter to the broad narrative of national policy. All too often, public policy affecting adult learners in England has been fragmentary and unstable, and financing short term, or non-existent. Feast is followed by prolonged famine: central policy imperatives distort local responsiveness; and when genuinely popular initiatives take off, they are all too quickly closed down - for fear that they will cost too much (Taylor 2005).

Adult learning policy - from the local to the national

The development of educational opportunities for adults in England through much of the Twentieth Century happened in the main through 
local development, responding to local demand, with spasms of State interventions. In the aftermath of the First World War government funded universities and the WEA, and put in place regulations enabling local authority provision which grew rapidly particularly in cities. (Ministry of Reconstruction, Board of Adult Education, 1919)In the Second World War government set up the Army Bureau of Current Affairs, to 'keep the soldier alert with a view to increasing his military efficiency' and 'to maintain his morale'(Haining, cited in Broad, 2013:124). Perhaps the single most significant government initiative to expand adult opportunity was the establishment of the Open University in 1969. But apart from these interventions, and the occasional policy commission (Ashby ,1954, Russell, 1973, and the Advisory Committee for Adult and Continuing Education,1982), government left the education of adults to local providers, and decisions about curriculum to professionals - and, in the case of WEA and to some extent university provision, significantly to students.

Locally planned and delivered adult education developed a rich portfolio responding to adults' needs and interests. When I began work in 1973 at a liberal arts adult centre in Brighton, I discovered an astonishing mix of provision. A politics class on the Arab-Israeli conflict engaged some seventy adult learners, alongside classes on the 
nineteenth century novel, advanced Russian, and a WEA philosophy tutorial; a group were looking at the impact of planning on the urban environment, and pensioners were planning to paint the night away. Not much later, Allen Ginsberg and Yevgeny Yevtushenko led sessions reading and debating their poetry.

Municipal adult education - that offered by local authorities - offered a different blend of provision, with more craft based and hands on courses. In the 1980s, the Inner London Education Authority (ILEA) Adult Education Institute where I worked offered women's selfdefence; woodwork for blind people; boxing; stained glass making (with perhaps two working class students alongside a dozen more affluent); and world championship level Latin American Dance classes. As well as languages, dressmaking, car maintenance, it offered programmes in popular planning, and starting a small business (Tuckett 1988).

The night school tradition, where adults who missed out at first undertook serious and systematic study to gain qualifications, was alive and thriving in further education colleges and polytechnics.

Universities accepted a civic responsibility to foster an informed population, and broadcasters fulfilled their duty to inform as well as educate and inform with flair. Libraries, and the advent of cheap 
paperbacks, also contributed (Field 2006). And yet, despite this variety, these services succeeded much better at meeting the needs of middle class adults, with extensive post-school education than in reaching working class adults, those who missed out at school, or disabled people.

The Russell Report on adult education, the result of a six year government sponsored enquiry, published in 1973 recognised the failure to serve significant sections of the population and called for a renewed focus on the needs of what were then called 'disadvantaged adults'. The report was shelved by Margaret Thatcher, then Secretary of State for Education, but shaped the work of local authorities and the WEA over a generation. The national campaign to secure 'A Right to Read' for adults, which was developed in the voluntary sector, supported by a BBC prime time television series, and only then adopted by government, became a core part of adult provision - in adult education centres and colleges alike. Literacy classes published their own writing, since working class experience was so seldom captured in print (Mace 1979, Crowther, 2001). English for Speakers of Other Languages work followed (Roberts et al 2007). There was also increased sensitivity to strategies to offer inclusive learning for people with disabilities. Again, Access courses opening routes to higher 
education for adults (and overwhelmingly to women) were developed locally by polytechnics and only later developed into a national initiative. (Ministry of Education 1954, DES, 1973, ACACE 1982, Parry and Wake 1990).

Following the Russell Report's recommendation, and with the support of local authorities, a new adult residential college was created. From its outset Northern College invested in an outreach worker, to go around Working Men's Clubs, tenants' groups, and miners' welfare associations, to discover how the College could best meet their needs. The work needed patience, and there was little initial response as mutual confidence was built. Three years in, it was clear that the investment was invaluable - and the College maintains the confidence of the working class communities it serves today. However, modern accountability systems make the open-ended investment needed to build such confidence difficult to justify (Ball and Hampton 2004).

\section{Nationalising policy}

The changes that led to the nationalisation of policy, and the increasingly narrow focus on courses with an explicit utilitarian labour market value derived from two sources. First, the then (Labour) Prime Minister, Jim Callaghan gave a speech in 1976 at Ruskin College, 
Oxford, ${ }^{3}$ raising concerns about standards and the liberalism of curricular and organisational arrangements in schools, and unleashing debates and initiatives which culminated in the Education Reform Act and the adoption of National Targets for Education and Training in 1988. The Further and Higher Education Act of 1992, further weakened the role of local authorities, 'freeing' colleges (if in practice shifting control to national funding agencies), and turning polytechnics into universities, as well as nationalising qualifications bearing adult education funding (Hodgson 2015). At the same time, the independence of Her Majesty's Inspectorate was ended ${ }^{4}$, and the new Further Education Funding Council inspectors were charged with a radically different balance of inspection and development from their predecessors, with a focus on measuring success in easily auditable judgements.

This process connected, eventually, with the second change- where post-compulsory education came to be seen as a subsidiary contributor to wider economic policy, with the Treasury exercising increasing control over its strategic direction. But before this second process took

\footnotetext{
${ }^{3}$ Callaghan's speech is reprinted in Jarvis \& Griffin (2003a), pp. 144-149.

${ }^{4}$ Her Majesty's Inspectorate was free standing and independent until 1992. After that date the independence ended, as responsibility for judgment about quality in further education transferred to the Further Education Funding Council (FEFC)Inspectorate, which reported to the FEFC Chief Executive. In 2002, following further reorganisation responsibility transferred to a newly created Adult Learning Inspectorate, and again from 2008 to the Office for Standards in Education (OfSted), whose remit, like FEFC's and ALI's, focused on inspection rather than development of high quality provision.
} 
hold in the early 2000s, a combination of circumstances created a flowering of life-wide as well as life-long learning initiatives, stimulated by State action in the 1990s.

\section{The golden age?}

In 1993 the European Commission published a White Paper which argued that economic prosperity and social cohesion were both enhanced by lifelong learning (CEC 1993). It launched debates in the European Union that embraced vocational and community education, which quickened during the European Year of Lifelong Learning in 1996, and culminated in the Lisbon Strategy in 2000 (European Council of Ministers 2000, Milana and Holford 2014 ). The accession of Sweden, Denmark and Finland had a positive effect on policies affecting community based learning, as could be seen from the Union's Grundtvig programme.

1996 also saw the publication of two major reports on lifelong learning. Building on the 1972 Edgar Faure report Learning to Be, (Faure 1972) a UNESCO committee, chaired by Jacques Delors, produced Learning: The Treasure Within, with its four pillars of learning:

- learning to know 
- learning to do

- learning to be

- and learning to live together. (Delors 1996).

Delors' analysis in the UNESCO report was grounded in a human rights focus, in which the key responsibility of a lifelong learning system is to support people in the full realisation of their capacities. To borrow from Carlyle, it saw 'the first duty of government to see that the people can think.' Delors' expansive and inclusive humanistic vision informed the 1997 World Conference on the Education of Adults in Hamburg (CONFINTEA V) which further drew attention to the way in which learning had an impact on work, health, longevity and wellbeing, on creativity and trust. Its vision was similar to that of Raymond Williams who argued in 1958 that at times of social change, adults turn to learning in order to understand what is happening, to adapt to change, and most importantly to shape it. Or as Paulo Freire put it, the task is reading the world, not just the word (UNESCO 1997, Williams 1993 (1958), Horton 1990, Freire 1975).

The second major report, Lifelong learning for all (OECD, 1996), a joint communique between OECD ministers of labour and education, linked adult learning to human capital formation, recognising that 
people's skills were an increasingly important driver of economic prosperity. OECD followed up with a raft of systematic studies of adult learning and education, and the exploration of links between lifelong learning and the labour market. As Kjell Rubenson notes, over time, the human capital focus that underpins OECD's analysis has come to be accepted as the norm in much of the industrial world, (especially in England), and increasingly in development education thinking as well, (Rubenson, 2015).

In Britain, the energy generated by these reports crossed party lines. In 1996 Gillian Shephard, the Conservative Secretary of State for Education, became convinced of the value of learning cities in helping decision makers at a local sub-regional level to pool resources across departmental boundaries, as her government adopted lifelong education policies. The Labour government then received five key reports on domestic policy at or just after it took office in 1997. The Dearing Report on higher education (Dearing 1997) highlighted among its four purposes of higher education, the need to 'create civic and inclusive societies' (Watson and Amoa 2007). Helena Kennedy's report on further education, 'Learning Works', (Kennedy 1997) included her pithy analysis of the weakness of the UK education system: 'If at first you don't succeed, you don't succeed'(Kennedy 1997:21), and made a 
powerful case for widening participation to people failed by initial schooling. Also reporting on further education, and the challenges it faced in making provision for people with disabilities and/or learning difficulties, the Tomlinson report Inclusive Learning (Tomlinson 1996), argued that it was the system not the learner that needed to make necessary adaptations to secure learners' right to learn. Josh Hillman's report, The University for Industry (Hillman 1996) ${ }^{5}$, led to the creation of a distance and blended learning institution, and, finally the Fryer Report, produced by the National Advisory Group for Continuing Education and Lifelong Learning (NAGCELL 1997) advised the Secretary of State on lifelong learning policies directly.

Apart from David Blunkett's Preface, The Learning Age showed how far a narrow utilitarian human capital focus was already shaping the thinking of his Department. However, the great flowering of policy initiatives the Labour government introduced (which included individual learning accounts, neighbourhood learning development, and a national literacy numeracy and ESOL strategy) was broad and inclusive, and drew strongly, not only on the UNESCO vision, and that of the domestic reports, but on Blunkett's own lived experience.

\section{Wider benefits of adult learning}

\footnotetext{
${ }^{5}$ Key excerpts from Hillman's report are reprinted in Jarvis \& Griffin (2003b), pp. 313-321.
} 
Two research centres were established by the Labour government to provide research evidence to underpin developments in lifelong learning. One focused on the economic benefits of lifelong learning, the other on the wider benefits of learning. The wider benefits work generated widespread interest in securing evidence of the impact of participation in adult learning on other social policy issues, and was subsequently picked up and developed internationally by OECD (UK Labour Force Survey 2003). A research report in 2012 summarised findings of the benefits that could be measured, concluding that the largest impact was on health and well-being, with a more modest influence on civic participation. For mental health and well-being the study showed participation in learning had more than twice the impact of being employed on self-confidence; for physical health it reported reduced visits to a doctor; a greater desire to get a job; higher levels of civic participation, with an upsurge in volunteering, and increased interaction among family members, alongside self-report of improved mental well-being. (BIS,2012c, Feinstein et al 2008). These findings confirmed the conclusion of the cross-government Foresight study on mental capital and well-being in 2008, that learning was one of five key things to do each day to foster mental well-being (HMSO 2008). 
To bring these figures to life, a Derbyshire care home reported that following the introduction of classes, including exercise classes, there was a 75\% drop in the use of incontinence pads, and a 50\% drop in inday medication. In their findings drawn from the British birth cohort studies the Wider Benefits of Learning centre discovered that people who had taken up classes were $13 \%$ more likely to give up smoking than their peers. The figures relating to racial tolerance are more graphic when compared with people of a similar age who report no participation in learning, and allowing for other variables, learners who have taken three or more classes over seven years show a $73 \%$ increase in racial tolerance (Feinstein et al, 2003). For people recovering from poor mental health, classes offer a freely chosen option for rebuilding social contact (HMSO 2008). Adult educators regularly report that quite apart from the stimulus offered by affordable classes, they are a route for many to overcome isolation and loneliness. However, perhaps the most striking finding of the birth cohort studies was that wider benefits were measurable whatever the subject or level of study undertaken, and whatever the prior educational experience of participants. Clearly, it is learning itself, whatever the subject,that is a key skill - both for productive work or wider social engagement (Schuller et al 2004). 
The evidence posed (and poses) significant challenges for government, since it operates in policy silos. If, as the evidence shows, participation in education secures improvements in health, both the health and further education ministries want provision to be made, but find it harder to decide from which budget the costs should be drawn. In any case the evidence is challenged, on the basis that the research shows a powerful association between participation and wider benefits, but does not show cast iron causality. The same is, of course true of the relationship between qualifications and productivity - the only difference lying in the willingness or scepticism of decision makers to accept the evidence.

There are important lessons and important challenges posed by the wider benefits work. The key lesson is that you cannot be certain of the purposes of the learners, or of the benefits they derive, from the title or category of the courses they join. There is always an interplay between skills acquired, personal confidence and social engagement.

\section{Inequality}

The challenge arising from the Wider Benefits of Learning work is, though, a stark one. If learning is so beneficial, why do so many people decide that it is not for them? Opportunity, of course, plays its part. Whilst it is clear that skills have an impact on labour market 
success, access to learning at work remains sharply differentiated, with people with fewer formal qualifications getting fewer opportunities to learn at work. Negative experience at school plays its part, too. Success in learning early in life leads to reinforced success; and if you see learning as irrelevant to your life, there is a strong chance your children will, too (Gorard 1998, 2007, White 2012).

Countries with market driven economic policies, and minimal regulation firmly in place, as in the UK and USA, experience sharply increased levels of inequality. As Wilkinson and Pickett demonstrate powerfully in The Spirit Level more unequal societies suffer poorer health, higher mortality rates, increased levels of crime, higher levels of social isolation, and lower levels of trust for rich and poor alike - all issues where learning has beneficial effects. And of course, they have populations with sharply differentiated levels of educational experience and achievement, in which marginalised groups are significantly under-represented (Wilkinson and Pickett 2009).

From the mid-1990s to early in the 2000s government surveys on adult participation in learning were undertaken in parallel to an annual series of representative sample surveys commissioned by the National Institute of Adult Continuing Education (NIACE). Both regularly confirmed the continuing power of Helena Kennedy's analysis. 
Participation is sharply differentiated by social class, by employment status, and by age - with participation dropping with every decade of the life-course. The surveys showed, too, how those who regularly learn plan to carry on doing so, whilst less than one in five adults who say they have done no learning since school plan to do so in the future. The symmetry in the findings is striking, but it is important to remember that there is nothing inevitable about them. (Snape et al 2005, Bienart and Smith 1998, Sargant et al 1997, White 2012). Respondents to a qualitative study on participation, who reported no learning since school, recognised that taking part in learning made you feel better about yourself, and helped you help your children get on, but still didn't see it as 'for the likes of us' (McGivney 1989).

\section{Motivation}

In response to the research, the Labour government made a commitment to devise strategies to engage and motivate adults to learn - especially for those adults who were failed by initial education and who as a result didn't see a role for learning in their lives. It was recognised that motivation is a key part of the curriculum. Harbans Bhola distinguishes between adult education as sector (registers, classes, formal structures and administration), and adult education as 
culture - employing radio, television, and public manifestations to engage people in learning. (Bhola 1997, Bhola 2011). In the spirit of adult education as culture, government mounted literacy 'adverts' on prime time television. In the same vein NIACE co-ordinated annual Adult Learners' Weeks - an initiative later adopted by UNESCO which has since spread since to 55 countries. The Week was based on the simple proposition that if you celebrate existing learners in all their diversity, it will encourage others to join in. By involving television stations, the press, thousands of local organisations; by establishing a free telephone learning advice helpline for adults to ring, and by putting a slip of paper encouraging them to do so along with their weekly pay-cheque for all the country's unemployed adults, the project reached a far wider range of potential participants than conventional marketing of educational opportunities. In the first year 55,000 people phoned the helpline; more than half were long term unemployed; within three months half had taken up a course (Tuckett, 1997).

\section{The turn to skills}

The innovation, experimentation and research affecting life-wide learning during David Blunkett's years as minister culminated in the inclusive remit given to the Learning and Skills Council (LSC), which 
was set up in 2002 to take responsibility for vocational, work-based and community education for young people and adults. The remit letter was richly informed by Blunkett's inspiring vision, calling for the LSC to work with local partnerships, equality councils, and trade unions to extend access for young people and adults:

I look to the [Learning and Skills] Council to increase the demand for learning by adults, and to increase the supply of flexible, high-quality opportunities to meet their needs. This is central to our goal of a learning society - a society in which everyone can share in the benefits of learning, enabling people to discover new talents, stretching their creativity and widening their opportunities. It is important that, at the start of the 21st century, all adults continue to develop their competence for the labour market, and reinforce their ability to be active family members and citizens. This includes provision for the growing proportion of older people.

The Council's role starts with its new duty to encourage individuals - adults as well as young people - into education and training. The Council must spearhead the drive to widen adult participation in Further Education, increasing the number drawn from those whose background or circumstances have disadvantaged them. The Council also needs to develop ways to draw into learning those people who have not engaged in any structured learning in the previous three years, building on the existing practice of educational broadcasters, Ufl, Adult Learners Week, and other initiatives, and working with local authorities in the context of their continuing role in adult and community learning. The Council should also look to continue and develop existing routes for adults into Higher Education such as Access to Higher Education courses.

I also expect local Learning and Skills Councils to play an active role in building the capacity of people living in deprived neighbourhoods, and to promote equality and social inclusion (Blunkett 2000, paras 46, 47, 24).

It was, however, set aside within months of his departure from Education to the Home Office (Blunkett 2000). The chair and 
leadership of the new LSC reinterpreted their remit to focus on qualifications-bearing courses focused on meeting the needs of the labour market to the detriment of life-wide learning. The influence of the Treasury increased significantly: testing, target setting and inspection regimes increased, and each year a new Skills Strategy was published. It was unsurprising, perhaps, that politicians soon argued that 'we don't want to pay for willow weaving on the taxes', or underwater basket weaving, or tap dancing... the examples were legion, and often acted as a smokescreen for cutting literacy and ESOL provision. One of Blunkett's successors as Secretary of State, Alan Johnson, explained cuts in community based adult education in this way: We must rebalance taxpayers' money towards the subjects where there is greatest need - so more plumbing, less Pilates; subsidised precision engineering, not over-subsidised flower arranging, except of course where flower arranging is necessary for a vocational purpose. Tai chi may be hugely valuable to people studying it, but it's of little value to the economy.' (Macleod, 2006).

It is a superficially powerful argument, fuelled by the particular challenges facing the British economy, but its weaknesses were highlighted in a story told by Tom Wilson, director of education at the 
Trades Union Congress, who was having plumbing work done in his house, and asked why plumbers don't take on apprentices. The plumber answered that as soon as the apprentices qualified they became competition, but that plumbers did engage apprentices after they reached forty, when getting underneath the bath to reach pipes became harder. 'But I don't need to', concluded the plumber, 'because I do pilates!'

Like Alan Johnson, ministers and officials now accepted the primacy of the OECD human capital approach to lifelong learning. Education was simply seen as a mechanism for economic modernisation, and resources needed to be focused to that end. The UK government ${ }^{6}$, as others in Europe, clearly recognised that economic competitiveness requires skilled and flexible workers for three key reasons.

First they were needed because of changes in the global economy. We live in what Gita Sen calls a fierce new world, where the combination of economic restructuring, disruptive technologies, communications transformations, and political instabilities have created a situation where we are, to use Charlie Leadbetter's graphic phrase, 'living on thin air'(Sen, 2012, Leadbetter, 1999).

\footnotetext{
${ }^{6}$ Since the late 1990 s various devolution measures have meant the UK government has direct responsibility for education only in England - hence the focus of this paper. However, it has retained a UK wide responsibility for economic policy.
} 
Outside the extractive industries (which are quite clearly tied to place), commodities can be designed in Italy, produced in Viet Nam, shipped by a Panamanian freighter, financed from London, advertised in New York, and show profits in the Cayman Islands; and any one of the elements in the chain can shift at extremely short notice to another low cost venue on another continent. For industrial societies, it is high skilled work that can compete in these markets, offering high levels of reward to globally mobile workers.

Second, the power of national governments to manage these forces has lessened significantly, when capital has global freedoms unmatched by common regulatory systems. However, there has been in most industrialised countries an ever greater focus on sectors where high levels of skill are required, and, unlike in England, a move away from education systems focused exclusively on the education of the young. Indeed, the evidence of the value of learning beyond school was underlined emphatically in the OECD's Skills Outlook. It remarked that 'at the country level there is a clear relationship between the extent of participation in organised adult learning activities and average proficiency in key information-sharing activities' (emphasis added) OECD, 2013, 24). It noted, too, that adults maintain and enhance key information-related skills better from learning undertaken outside the 
workplace than from work-based training. British Treasury thinking, however, concentrated more on the greater rate of return possible from investment in the young, a view reflected in the influential Leitch report (Leitch 2006).

Third, Alan Johnson, like his predecessors and successors, faced the fact that employers in the UK undertake less training than their continental competitors (Eurostat 207, 2015). This situation was exacerbated by Labour policies between 2003 and 2010, when the Train to Gain programme displaced funding for adults in colleges learning the things they want to learn - instead paying employers to offer training to their employees. It was a truly bizarre initiative -for instance government officials, desperate to hit targets, persuaded the supermarket chain, Tesco, that the government would pay for initial training that Tesco had until then funded itself. Other employers received funding for qualifications that merely confirmed employees' existing skills, with very high levels of 'deadweight' - public funding that merely displaced private funding. The current apprenticeship programme runs the same risks. (Hayes 2009; BIS 2012b) 
The UK Commission on Employment and Skills (UKCES) ${ }^{7}$ surveyed employers in 2012 to discover why they were resistant to training. The three most common responses were that 'staff don't want vocational qualifications' (30\%); they 'don't know enough about the vocational qualifications available' (28\%); and that 'government doesn't fund or give grants to cover costs' (28\%). Vocational qualifications are undoubtedly of key importance in securing a job initially, and of some significance when changing jobs. What is clear from the survey, however, is that they loom less large in employers' plans for workers already in post (UKCES 2012).

If things became tough for adult learners under Labour, they have got worse since. The 2015 Eurostat report on adult participation in formal and non-formal education showed that 20 of $28 \mathrm{EU}$ countries reported significant increases between 2009 and 2014. Alas, the UK reported the most significant fall - while $20.1 \%$ of its $16-64$ year-olds participated in education and training over a four week period in 2009, just $15.8 \%$ did so in 2014 . The UK's productivity continues to lag by up to $45 \%$ behind its European partners. (Eurostat 2015).

\footnotetext{
${ }^{7}$ The UKCES is 'a publicly funded, industry-led organisation that offers guidance on skills and employment issues' (https://www.gov.uk/government/organisations/uk-commission-for-employment-and-skills/about, accessed 11 Dec. 2016).
} 
In part the UK figures can be explained by the evidence from employers' own surveys that training provided by their firms is at lower levels than before the onset of the $2007 / 8$ recession:

Table 1. Percentage of employers training staff and offering off-site training over the previous 12 months

$$
\text { On-site Off-site }
$$

$2003 \quad 59 \quad n / a$

$\begin{array}{lll}2007 & 67 & 46\end{array}$

$\begin{array}{lll}2014 & 58 & 45\end{array}$

(LSC 2008, 3, UKCES 2014, 56)

But they also result from the radical reductions of publicly funded learning opportunities for adults that successive governments have implemented in the last decade as Treasury orthodoxy and austerity policies combined - and from their surely unintended actions in persuading employers that training is something the State should pay for.

Meanwhile, the UK bumps along the bottom of all the EU countries in the length of training time offered to individual workers (see Figure 1). If induction and statutory health and safety courses are stripped out, 
the volume of training, particularly among small and medium sized enterprises lags even further behind European competitors.

Figure 1

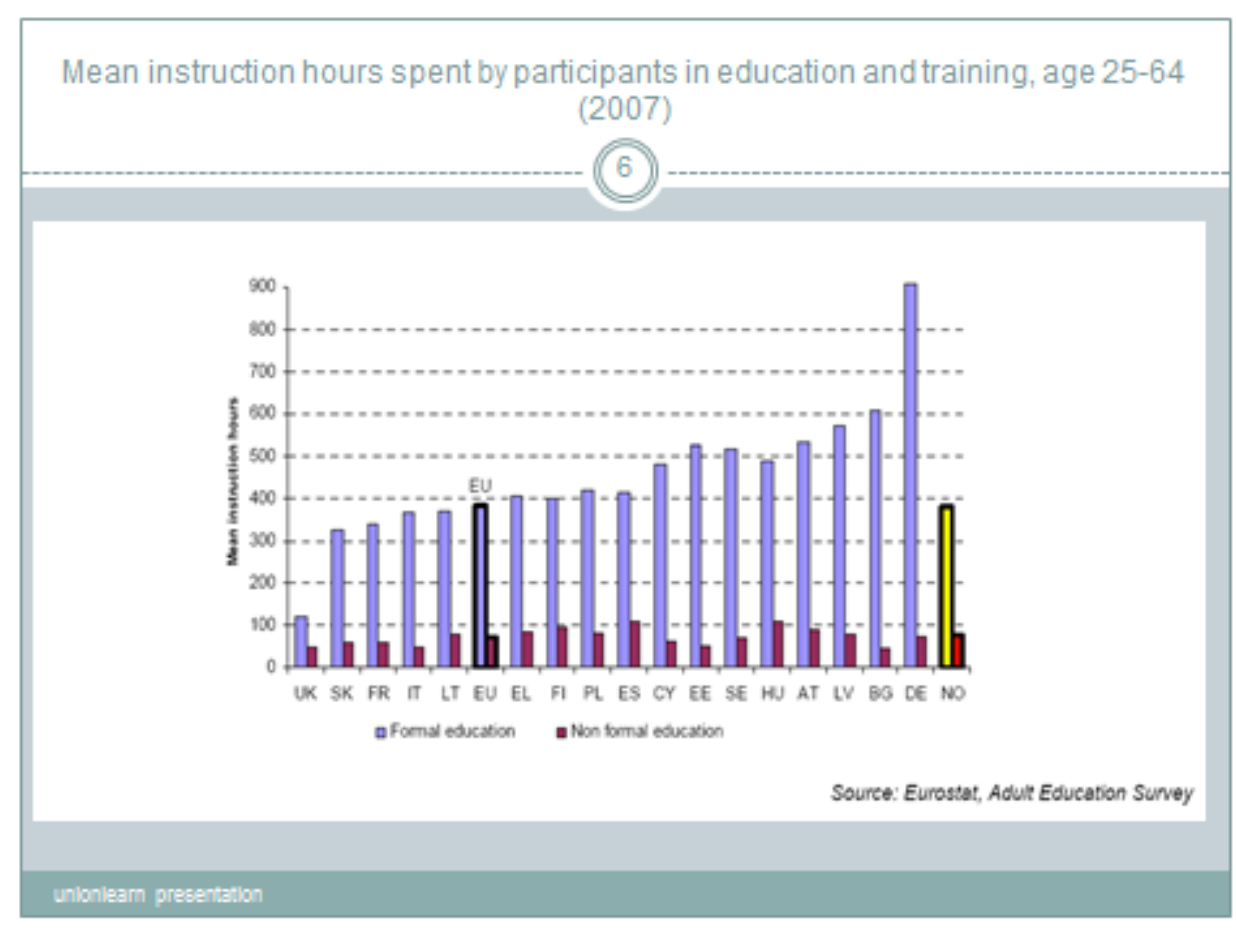

In addition, where the opportunity to train is offered, it is skewed heavily in favour of higher paid and already well qualified workers:

Table 2. Participation in formal or non-formal learning over the last year by level of prior educational achievement (UK)

Lower secondary (ISCED 0-2) $\quad 17.9 \%$

Upper secondary (ISCED 3-4) 33.5\% 
(Source: Eurostat 2015)

To add to the gloom, and perhaps most worryingly for English policymakers, OECD found that the UK (as represented by England and Northern Ireland) ${ }^{8}$ was among the three highest-performing countries in literacy when comparing 55-65 year-olds; but among the bottom three countries when comparing literacy proficiency among 16-24 year -olds (OECD, 2013 p.31); and that the younger cohort is no better prepared for the skill demands of the modern workplace than the older adults preparing to leave work. It is important, too, to note that the 16-24 year-olds went through their whole school careers under the centralised regime of a national curriculum, regular testing, and an inspection regime seeking compliance with government priorities.

\section{Culture rather than qualifications}

What is clear from the last decade is that narrow labour market focused policies, which have entailed swingeing cuts for all but officially sanctioned qualifications courses, have not worked. They have failed to increase the commitment to investing in workforce

\footnotetext{
${ }^{8}$ Neither the administrations in Wales or Scotland agreed to participate in the OECD PIAAC (Programme for the International Assessment of Adult Competencies) study. As a result UK results refer only to England and Northern Ireland.
} 
development. Neither - despite the rise in the number of qualifications awarded - have they succeeded in raising the overall skill levels of the workforce.

This is the result of a disproportionate focus on individual learners gaining qualifications. But in the workplace, like in society more widely, there is more to it than that. Lorna Unwin and Alison Fuller explored the distinction between 'expansive' workplaces, which value autonomy of decision making, reflection, and agency among workers, as against 'restrictive' workplaces where in the language of an earlier industrial era, workers are hired 'hands', required just to follow the rules. What Unwin and Fuller point to, as did Lave and Wenger in their earlier work on Communities of Practice, is the need for workplaces to foster a culture of learning - and that can best be done by fostering learning and curiosity of all sorts. Current policies fail to foster that culture not least because they are too narrowly focused on utilitarian aims and on auditable, short-term outcomes (Unwin and Fuller, 2003, Lave and Wenger,1991). The limited importance of qualifications was clear, too, in Alan Felstead and colleagues' large survey of how workers like to learn, which showed that trial and error, asking a friend, or a boss were all chosen ahead of taking a course (Felstead et al 2007). 
The Ford motor company's Employee Development Action Programme (EDAP) offers a vivid illustration of how life-wide learning can have positive effects on the workplace. The initiative, negotiated by Ford's unions as part of the 1987 pay bargaining round, agreed a sum of $£ 50$ per worker $(0.3 \%$ of the wage bill) to provide a fund for workers to undertake any kind of study other than industrial training, which was the company's responsibility. The programme was managed at plant level by representatives of blue collar and white collar unions and by management. It accepted a broad definition of learning. Workers took golf lessons, learned to drive, learned plastering. Within 3 years they were doing Open University degrees. In a company with a long history of poor industrial relations, and where the two yearly wage round regularly ended in a major strike, there was, following the introduction of EDAP, evidence of greater willingness to accept new procedures: absenteeism rates and staff turn-over both dropped, and pay rounds were negotiated without strikes. Other companies in the motor trade copied the scheme, and as Ford's staff numbers reduced, staff and management agreed to hold on to EDAP as a priority. (Moore, 1994) More recently, the success of Unionlearn the TUC's trade union learning initiative, highlights the benefits of engaging workers in the 
design, planning and delivery of learning in and for the workforce.

Unionlearn has recruited 30,000 workers as learning representatives, offering peer advice to colleagues on learning options, and negotiating with management on the learning needs of the workforce. Like in Ford, the impact of Unionlearn has been beneficial far beyond the acquisition of vocational skills. Here, as in community education, learning 'leaks' - and the skills you gain in one context can be applied in others. ${ }^{9}$

\section{Learning through life}

In Learning through life, the report of the independent Inquiry into the Future of Lifelong Learning Schuller and Watson (2009) offer a sharp contrast to current policy thinking, building their policy proposals on the needs of four relatively discrete life stages: labour market preparation and entry; job and family dominated adult life; an active third age, often combined with caring responsibilities; and later retirement. Introducing a series of essays in a special issue of the International Journal of Lifelong Education which enriched and extended the analysis in a number of ways (Jarvis 2010a), Peter Jarvis described Schuller's and Watson's life stages as ‘quite far-sighted, suggesting a new model of the lifespan which much more realistically

\footnotetext{
${ }^{9}$ https://www.unionlearn.org.uk/ (accessed 24 September 2016)
} 
reflects the age profile of the UK'(Jarvis 2010b: 398). Each stage has distinctive learning challenges.

It is striking how little current provision discriminates between the different aspirations and interests of these cohorts, which may be one reason for the extraordinary flowering of self-help provision by and for older adults who are already enthused by learning, through the University of the Third Age groups across the country. A 2007 study noted that as people age their interests in learning shift decisively away from labour market focused study to languages, art, history and philosophy (Aldridge and Tuckett, 2007).

Little of the rich mix of public provision of the 1970s highlighted above survives now. The needs of the already educationally confident are however, well-served. Master-classes aplenty are advertised daily in The Guardian newspaper; there are a plethora of single issue organisations; Saga has learning cruises for older people; and with the transformation of our lives the internet has shaped, including its explosion of on-line courses, and the success of MOOCs, a new mix of independent adult classes has taken the place of lost public provision. Certainly, we can take comfort from the observation that where adults have the confidence, and see the merits of coming together, literally or across the ether, to learn, they will invent the means to do so. 
That, surely lies behind the spread of book groups over the last fifteen years. It explains, too, the development of expert patient groups, like Parkinson's sufferers whose own research and dialogue ensures that patients meet their doctors on more equal terms, able to negotiate treatment regimes.

New forms of association, forged in the voluntary sector, offer opportunities to reconnect adult learning to social movements seeking change, and the skills participants pick up in shaping new bodies stay with them.

\section{A return to the local}

But these developments serve only the learning confident. Alongside voluntary action we need public support for life-wide learning - first to secure participation for under-represented groups; second to scale up effective innovations ( as in the adult literacy campaign); and third to guarantee access to properly qualified teachers and resources. To that end we need a mix of provision and providers, of course, with secure though doubtless modest funding. We need to insist that it is axiomatic that adults have a right to learn, backed by secure funding, to ensure access to under-represented groups. We also need outreach work, building alliances with community bodies, faith organisations and workplaces of all sorts. It is possible to make learning accessible, 
and it is possible to build alliances across the breadth of our communities to create vibrant learning cultures, where everyone can feel at home.

The way to succeed in doing this does not lie in national targets, inspection regimes, and short-term funding alone. It requires from all of us, wherever we work, determination, clarity of vision, and the belief that we can make a difference, for innovation is not solely the job of voluntary associations. From government it requires money of course, but more importantly trust - in the professionalism of teachers and organisers, and in the ability of local decision makers to find local solutions that respond to local needs.

The success of the Learning City movement across the world suggests that the alliances needed to create the cultural shifts central to making a learning culture are easier to forge at a sub-regional, or city level: as Jarvis (2008: 216) suggests, 'they offer more opportunity of the different sectors of society developing ways of working together to enhance the local community'. Where local leadership, and the active participation of local associations, agencies, employers, colleges and universities, combine to overcome silos and see the benefits of pooling resource; where strategy and tactics to address the needs of communities and of individuals alike are shared to help people sustain 
and transform their circumstances, we see the beginnings of a lifewide learning culture in which everyone has the chance to thrive. Learning cities and regions need to be imagined 'not merely as places of work and industry but as places of community, care and concern' (Jarvis 2008: 216).

But success in building learning cultures needs, too, the ability to listen. Twenty five years ago, a colleague of mine, researching the limited curriculum on offer to adults with learning difficulties met one student, who had, when offered an art class, woodwork or keep fit, responded, 'I want to learn Jesus and history, and thunder and lightning' (Sutcliffe, 1990, 142). The story has stayed with me, for it offers a benchmark against which to measure the range and depth of opportunities adults are afforded today, with its concern to understand the scientific and ethical underpinning of the lives we lead; and because it illustrates the importance of avoiding pigeon- holing people.

\section{Conclusion}

My argument in this paper is that English experience shows that a skills strategy focused on qualifications for work is necessary but not, on its own, enough. It needs to be complemented with one focused on lifewide learning that gives people a voice in shaping their learning; increased control over their lives, and which enables them to shape 
change, through contesting the inequality ingrained in our current system, to enable them to build together a culture of learning.

To be effective, a life-wide learning strategy needs to be locally shaped, and to include space to respond effectively to adults' appetite for learning, however unexpected. For that there is a need for government resourcing, but also a recognition that the blend best suited to different communities will be better decided locally.

'The primary aim of the learning society,' according to Jarvis (2008:

215) 'is to help people learn to love learning - a culture of learning and regard it as their civic responsibility to continue to learn.' We need life-long and life-wide learning together if we are to become such a learning society - one where, in the slogan of the former United Nations Secretary General, Ban-Ki Moon, no one is left behind. So, to sum up, we need plumbing and Pilates, Jesus and history, thunder and lightning.

Bibliography

ACACE (1982) Continuing education: From policies to practice : a report on the future development of a system of continuing education for adults in England and Wales, Leicester: Advisory Council for Adult and Continuing Education. 
Aldridge, F., and Tuckett, A., (2007) What older adults learn, Leicester: NIACE

Ball, M., and Hampton, W. (eds), (2004) The Northern College: Twenty-five Years of Adult Learning, Leicester: NIACE Baron, S., Field, J., \& Schuller, T., eds. (2001) Social capital: Critical perspectives, Oxford: Oxford University Press.

Bhola, H.S. (2011) 'Mobilising for adult learning: Reflective and festive events', in Derrick, J., Howard, U., Field, J., Lavender, P., Meyer, S., Nuissl von Rhein, E., \& Schuller, T., eds. Remaking adult learning, (pp123-127) Leicester: NIACE.

Bhola, H.S., (1997.) 'Transnational forces and national realities of adult basic education and training' Convergence, vol. XXX, no.2/3, pp. 41-50

Beinart, S. and Smith, P. (1998). National adult learning survey 1997. Sudbury: DfEE.

BIS. (2012a). National Adult Learning Survey 2010: Technical Report, BIS Research Report 63a; London: BIS.

BIS (2012b) Assessing the deadweight loss associated with public investment in further education and skills BIS research report, no. 71 London: BIS BIS (2012c) Review and update of research into the wider benefits of adult learning, BIS Research paper no.90, London, BIS

Blunkett, D. (1998) 'Preface' in DfEE The learning age: a renaissance for a new Britain, London: The Stationery Office.

Blunkett (2000) The Learning and Skills Council: strategic priorities http://dera.ioe.ac.uk/13613/1//sc-remit-letter.pdf (accessed 29 September 2016) 
Blunkett D. (2000) Remit Letter sent to the Learning and Skills Council http://dera.ioe.ac.uk/13613/1/lsc-remit-letter.pdf (accessed 2 June 2016).

Boseley, S. (2015) 'Vince Cable: adult education helped my mother overcome mental illness', Guardian 10 March 2015

http: / / www.theguardian.com/society/2015/mar/10/vince-cable-adult-educationmental-illness-speech accessed 3 October 2015

Broad, R.,(2013) The radical general: Sir Ronald Adam and Britain's new model army 1941-46, Stroud, Spellmount, The History Press.

Commission of the European Communities (1993) Growth, competitiveness, employment: the challenges and ways forward into the twenty first Century White Paper, COM (93) 7005 December 1993, Parts A and B, Brussels: CEC.

Crowther, J., Hamilton, M., \& Tett, L. (2001). Powerful literacies. Leicester: NIACE

Dearing, R. (1997) Higher education in the learning society, (The Dearing Report), The National Committee of Inquiry into Higher Education, London: HMSO Delors, Jacques (ed) (1996). Learning: The Treasure Within, UNESCO Paris, 1996. DES (1973) Adult education (Russell report) London, HMSO European Council of Ministers (2000) Lisbon European Council 23 AND 24 March 2000: Presidency Conclusions accessed via the website of the European Parliament http://www.europarl.europa.eu/summits/lis1_en.htm 3 October 2015 
Eurostat (2007) Adult Education Survey

http://ec.europa.eu/eurostat/cache/metadata/en/trng_aes_12m0_esms.htm accessed 3 October 2015

Eurostat (2015) Lifelong learning, 2009 and 2014 (\% of the population aged 25 to 64 participating in education and training). Available at :

http://ec.europa.eu/eurostat/statistics-

explained/index.php/File:Lifelong_learning,_2009_and_2014_(\%C2\%B9)_(\%25_of_th

e_population_aged_25_to_64_participating_in_education_and_training)_YB15.png (accessed 11 December 2016).

Faure, E., et al (1972) Learning to be : the world of education today and tomorrow Paris: UNESCO.

Feinstein, L.; Hammond, C.; Woods, L.; Preston, J.; Bynner, J. (2003) The Contribution of Adult Learning to Health and Social Capital. Wider Benefits of Learning Research Report, London: IOE. .

Feinstein, L., Budge, D., Vorhaus, J., Duckworth, K. (2008) The Social and Personal Benefits of Learning: A summary of key research findings, London: Centre for Research on the Wider Benefits of Learning.

Feinstein, L., Kirpal, S., \& Arévalo Sánchez, I. (2009). The wider benefits of learning. Handbook of technical and vocational education and training research. (pp. 354-359). Berlin: Springer

Felstead, A., Fuller, A., Unwin, L., Ashton, D., Butler, P., Lee, T. and Walters, S. (2004) Better learning, better performance: evidence from the 2004 Learning at Work Survey, Leicester: NIACE. 
Field, John (2006), Lifelong Learning and the New Educational Order, 2nd edition, Stoke on Trent: Trentham Books.Freire, P. (1975) Pedagogy of the oppressed, Harmondsworth: Penguin

Fryer, Robert (2010), Promises of Freedom: Citizenship, Belonging and Lifelong Learning, Leicester: NIACE.

Gorard, S., Rees, G., Fevre, R. and Furlong, J., (1998). Learning trajectories: travelling towards a learning society? 1. International Journal of Lifelong Education, 17(6), pp.400-410.

Gorard, S. and Smith. E. (2007). Do barriers get in the way? A review of the determinants on post-16 participation. Research in Post-Compulsory Education 12: pp 141-148.

Haining, Lt.Gen (1940) TNA, WO32/10462,43 Education 1296 (a report on educational facilities in the Army) cited in Broad, R.,(2013) The radical general: Sir Ronald Adam and Britain's new model army 1941-46, Stroud, Spellmount. Hayes (2009) cited in http://feweek.co.uk/2011/10/28/adult-apprenticeshipsbenefit-from-train-to-gain-funding/ (accessed 29.9.2016)

Hayes, J. (2010) 'The craft so long to lerne: skills and their place in modern Britain' speech given at the Royal Society of Arts, 26 October 2010, availabvle at: https://www.gov.uk/government/news/john-hayes-calls-for-a-new-arts-andcrafts-movement (accessed 3 October 2015).

Hillman, J., (1996) University for industry: creating a national learning network, London: IPPR. 
Hodgson, A.(ed.) (2015). The coming of age for FE? Reflections on the past and future of further education colleges in the UK London: Institute of Education Press Holford, J., \& Welikala, T. (eds) (2013). 'Renaissance” without enlightenment: New Labour's “Learning Age” 1997-2010’. Lifelong Learning in Europe. Cheltenham: Edward Elgar, 140-64.

Hollis, P. (1998). Jennie Lee: a life. Oxford: Oxford University Press.

HMSO (2008) Mental capital and wellbeing: making the most of ourselves in the 21st century Foresight study London: HMSO

Horton, M.(1990) The Long Haul: An Autobiography. New York: Teachers College Press.

House of Commons Innovation, Universities and Skills Committee (2008) Re-skilling for recovery: After Leitch, implementing skills and training policies, $1^{\text {st }}$ report session 2008-09, vol.2;

http://www.publications.parliament.uk/pa/cm200809/cmselect/cmdius/48/48ii.p df; accessed 25.9.16

Jarvis, P. (ed.) (2010a) The future of lifelong learning. Special issue of International Journal of Lifelong Education 29(4)

Jarvis, P. (ed.) (2010b) Inquiry into the future of lifelong learning. Introduction to Special Issue of International Journal of Lifelong Education 29(4), pp. 397-400.

Jarvis, P. (1983) Professional Education. Beckenham: Croom Helm. Jarvis, P. (1992) Theory and practice and the preparation of teachers of nursing. Nurse Education Today 12(4), pp. 258-265 
Jarvis, P. (1998) The Practitioner-Researcher: Developing Theory from Practice. San Francisco: Jossey-Bass.

Jarvis, P. (2005) Lifelong education and its relevance to nursing. Nurse Education Today 25(8), pp. 655-660.

Jarvis, P. (2008). Democracy, lifelong learning and the learning society: Active citizenship in a late modern age. London:Routledge

Jarvis, P. \& Griffin, C., (2003a) Adult and Continuijng Education: major Themes in Education. Volume I. Liberal Adult Education (Part 1). London: Routledge.

Jarvis, P. \& Griffin, C., (2003b) Adult and Continuijng Education: Major Themes in Education. Volume III. Vocational Education. London: Routledge.

Kelly, T. (1970). A history of adult education in Great Britain (Vol. 31). Liverpool: Liverpool University Press.

Kennedy, H., (1997) Learning works: widening participation in further education, Coventry: Further Education Funding Council.

Lave, J., and Wenger, E., (1991) Situated learning: legitimate peripheral participation Cambridge: Cambridge University Press

Leadbetter, L., (1999) Living on thin air: the new economy Harmondsworth: Viking Leitch, S. (2006) Prosperity for all in the $21^{\text {st }}$ century (The Leitch Report), London: HM Treasury (hm-treasury.gov.uk/leitch)

LSC (2008) National employer skills survey 2007: key findings

https://www.gov.uk/government/uploads/system/uploads/attachment_data/file/ 303566/2007nat-nessurvey2007keyfindings-may08.pdf accessed 5 October 2015

Mace, J. (1979). Working with words. London: Chameleon.

Macleod, D., (2006) ‘Johnson: Fund more plumbing and less pilates’ Guardian, 7 June 2006 
http://www.theguardian.com/education/2006/jun/07/furthereducation.uk1 accessed 3 October 2015

McGivney, V. (1989) Education's for other people, Leicester: NIACE.

Milana, M., \& Holford, J. (2014). Adult education policy and the European Union: theoretical and methodological perspectives. Dordrecht: Sense Publishers.

Ministry of Education (1954), The organisation and finance of adult education in England and Wales (Ashby report) London, HMSO.

Ministry of Reconstruction, Board of Adult Education (1919) Final report (1919 report) HMSO: London

Moore, R. (1994) ‘Ford EDAP: Breaking Through The Barriers', Adults Learning, May 1994, pp 225-226. (Reprinted in Jarvis \& Griffin (2003b, pp. 113-115.)

NAGCELL (The National Advisory Group on Continuing Education and Lifelong Learning) (The Fryer Report),(1997) Learning for the Twenty-First Century, London: DfEE

OECD (1996) Lifelong learning for all, Paris: OECD

OECD (2013) OECD skills outlook 2013: first results from the survey of adult skills, Paris, OECD.

Parry, G., and Wake, C. eds. (1990) Access and alternative futures London: Hodder and Stoughton.

Roberts, C., Cooke, M., Baynham, M., \& Simpson, J. (2007). Adult ESOL in the United Kingdom: Policy and research. Prospect Vol. 22, No. 32007 pp.18-31 
Rubenson, K., (2015) 'Framing the adult learning and education policy discourse: the role of the Organisation for Economic Development and Co-operation' in Milana, M., and Nesbit, T., Global perspectives on adult education and learning policy, (pp179-183 Basingstoke: Palgrave Macmillan

Sargant, N., with Field, J., Francis, H., Schuller, T., \& Tuckett, A. (1997). The Learning Divide. Leicester: NIACE.

Schuller, T., Preston, J., Hammond, C., Brassett-Grundt, A., and Bynner. J. (2004), 'The Benefits of Learning: The Impact of Education on Health, Family Life and Social Capital, London: Routledge Falmer.

Schuller, T., and Watson, D., (2009) Learning through life, Leicester: NIACE. Sen, G., (2012) 'Surviving the fierce new world', Development, 55(3), 266-268. Skills Funding Agency/BIS (2016) Statistical first release Further Education and Skills: Learner participation, outcomes, and level of highest qualification held; Coventry: SFA/BIS; (https://www.gov.uk/government/statistics/furthereducation-and-skills-statistical-first-release-june-2016 accessed 25.9.16)

Snape, D., Tanner, E., Sinclair, R., with Michaelson, J., and Finch, S. (2007). National adult learning survey (NALS) 2005. London: DES.

Sticht, T.,(2001) Literacy in War and Peace: Tom Sticht's Work in Adult Literacy Education http://www.en.copian.ca/library/research/sticht/nov01/page1.htm, accessed 3 October 2015

Sutcliffe, J., (1990) Adults with learning difficulties, Milton Keynes, Open University Press. 
Taylor, R. (2005). Lifelong learning and the Labour governments 1997-2004. Oxford Review of Education, 31(1), 101-118.

Tomlinson, J (1996) Inclusive learning Coventry: Further Education Funding Council.

Tuckett, A. (1988) The jewel in the crown London: ILEA

Tuckett, A., (1997). Motivation is curriculum: stimulating demand for further education among under-represented groups by collaboration with the media in Sargant, N. and Tuckett, A., Pandora's Box (pp45-68) Leicester: NIACE UK Labour Force Survey (2003) Education and skills: The economic benefits, Spring 2003, London: DES p17.

UKCES (2012) Employer Perspectives Survey London: UKCES

UKCES (2014) Employer Perspectives Survey: UK results London: UKCES

UNESCO (1997) The Hamburg declaration and Agenda for the future Fifth International Conference on Adult Education 14-18 July 1997 (CONFINTEA V) Paris: UNESCO

Unwin, L. and Fuller, A. (2003) Expanding Learning in the Workplace, NIACE: Leicester: NIACE.

Watson, D., \& Amoah, M. (2007). The Dearing Report: ten years on. London: Institute of Education, University of London.

White, P., 2012. Modelling the 'learning divide': predicting participation in adult learning and future learning intentions 2002 to 2010. British Educational Research Journal, 38(1), pp.153-175. 
Wilkinson, R., and Pickett, K. (2009) The Spirit Level: Why Equality is Better for Everyone, Penguin, London.

Williams, R., (1993 (1958)) 'Culture is ordinary’ in Mcllroy, J. and Westwood, S., (eds) Border Country: Raymond Williams in Adult Education, NIACE, Leicester 